\title{
Strategic Priorities of the Innovative Development of Crop Production in the Pskov Region
}

\author{
I.S. Sandu ${ }^{1}$ and I.P. Voiku ${ }^{2 * *}$ \\ "Corresponding author: voiku-ivan@ yandex.ru \\ ${ }^{1}$ FSBSI FRC of land economy and social development of rural areas - All-Russian Agricultural Economics Research Institute, \\ Moscow, Russia \\ ${ }^{2}$ FSBEI of Higher Education Pskov State University, Pskov, Russia
}

\begin{abstract}
The article substantiates the relevance of the strategic approach to solve the problems of the innovative development; the author's definition of the strategy of the development of innovative processes is given; the place of strategic planning in the technological sequence of strategy development is determined. The structure of strategic planning documents developed at the federal and regional levels in the Russian Federation is presented. The structure of the sectoral documents of strategic planning of the Russian Federation is defined. A system of strategic planning in the field of crop production of the Pskov region, including the federal, interregional and regional levels, as well as general and sectoral documents is developed. The main priorities of the innovative development of crop production in accordance with the sectoral structure of the strategic planning documents of the Russian Federation are determined. The relevance of the choice of the strategic priorities in solving the problems of crop production of the Pskov region is formulated.
\end{abstract}

Keywords: strategy, priorities, innovations, document, planning, crop production.

\section{Introduction}

In the context of geo-economic transformations, the agricultural sector of the Russian Federation faced a number of challenges that determined the need to update the technical and technological base of the crop production on a qualitatively new basis and the transition to a qualitatively new innovative type of development.

However, the current management model makes it difficult to increase the pace of production development, does not allow to implement the scenario of intensive sectoral development. The existing mechanisms of state support of agricultural goods producers make it difficult to implement and develop the results of research and achievements.

\section{Problem Statement}

An integrated strategic approach is required to solve the problems of innovative development.

The strategy of the development of innovative processes is the process of formulation of systemic strategic decisions, the implementation of which will ensure a balanced development of innovative activities of enterprises in a given period, providing competitive advantages of the industry [1].

Strategic planning plays a key role in the technological sequence of development strategy of innovative processes the process of goal-setting, planning, programming and forecasting, designed to solve the problems of securing sustainable development of the Russian Federation, its subjects and municipal structures, as well as various sectors of the economy and public administration [2].

\section{Research Questions}

The structure of strategic planning documents, developed at the federal and regional levels in the Russian Federation, is shown in figure 1. 


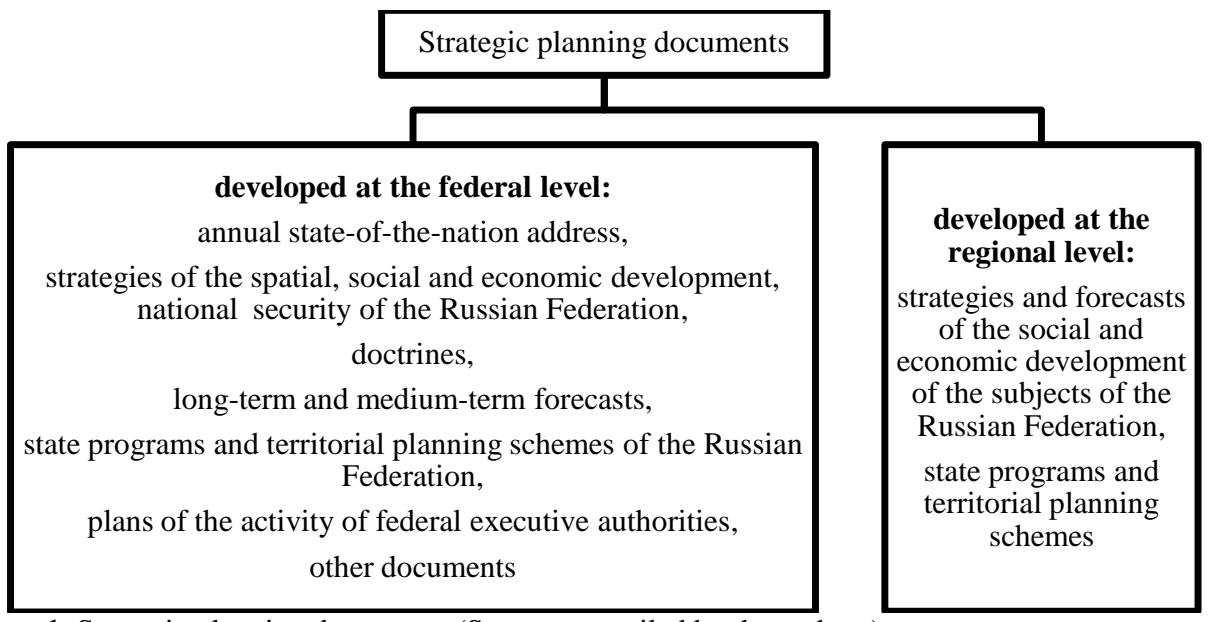

Figure 1. Strategic planning documents (Source: compiled by the authors)

Sectoral strategic planning documents of the Russian Federation - documents that determine the development of a particular industry or sphere, should be the basis for the development of elaboration of programs, territorial planning schemes, and other planning and program documents.

According to the decision of the President or the government of the country, sectoral strategic planning documents of the Russian Federation may contain such elements as an action plan for a certain period, as well as the time frames, stages and expected results of the planned activities, and other provisions [2].

\section{Purpose of the Study}

We define the main priorities of innovative development of crop production in accordance with the sectoral structure of the strategic planning documents of the Russian Federation (Fig.2).

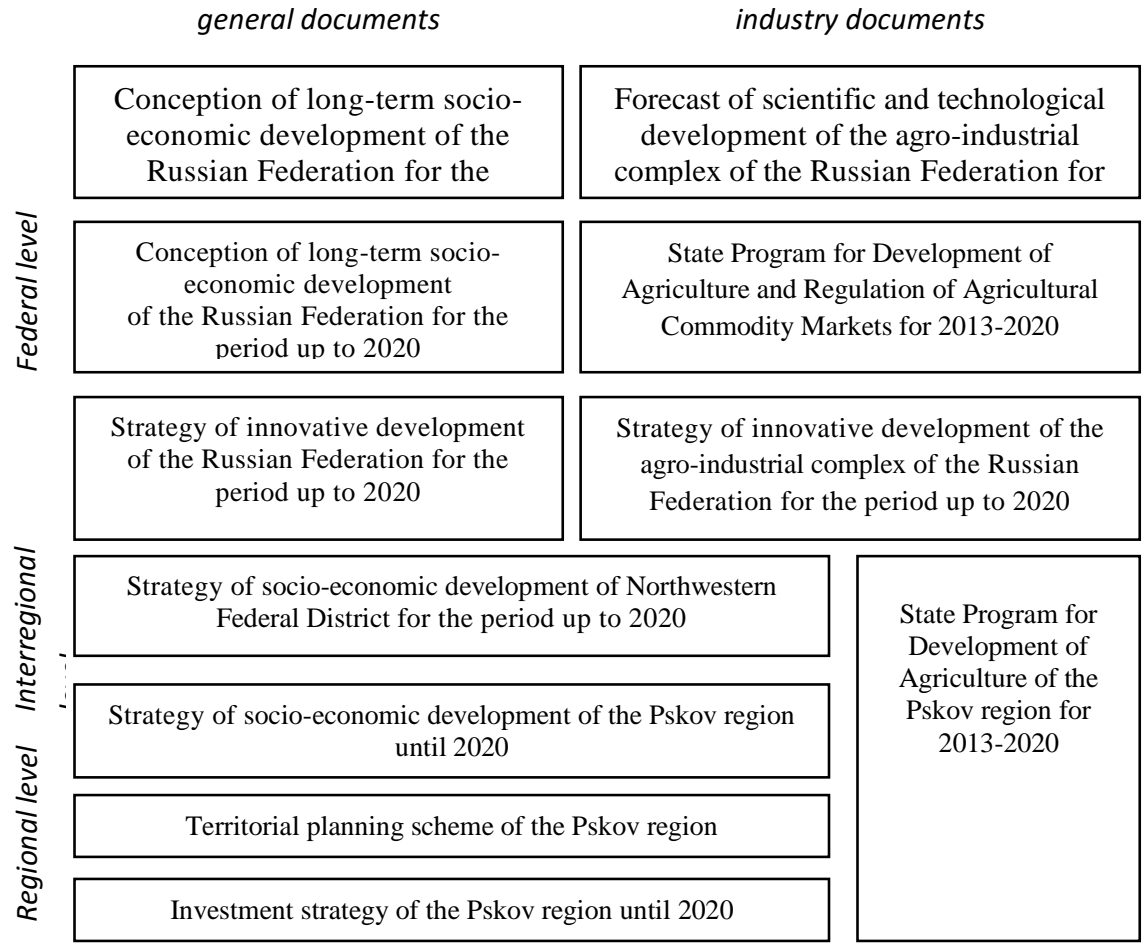

Figure 2. Strategic planning system in the crop production of the Pskov region (Source: compiled by the authors)

Strategic issues of the development of innovative processes in crop production are considered to some extent in each of the presented elements of the strategic planning system. 


\section{Research Methods}

We will review the content of strategic planning industry documents: action plan, time periods and stages of their implementation, expected results, and other provisions. We will identify the provisions, directly or indirectly related to the object of research, namely, to the innovative development of crop production.

\section{Findings}

In accordance with the Conception of long-term socio-economic development of the Russian Federation for the period up to 2020, the main strategic guidelines for the long-term socio-economic development are:

1. Strengthening the role of innovation in socio-economic development and reducing the impact of many traditional growth factors [3].

2. Modernization of traditional sectors of the Russian economy, including agriculture.

3. Transformation of innovations into the main factor of economic growth and increase of labor productivity by 3-5 times in the sectors of the economy which determined the competitiveness of the national economy, as well as reduction of energy intensity of the sectors of the economy by an average of 1.6-1.8 times.

Innovative development of sectors of the domestic economy in 2008-2020 should take place in 2 stages. The first stage (from 2008 to 2012), according to the developers of the concept, was based on the implementation and expansion of the existing competitive advantages of traditional spheres and industries. The second stage (from 2013 to 2020) is the transition of the domestic economy to a fundamentally new technological base, including the transition of the agroindustrial complex to stable development by strengthening Russia's position in the world food markets.

In accordance with the Forecast of long-term socio-economic development of the Russian Federation for the period up to 2030, the development of the agro-industrial complex is possible under two scenarios:

1) Innovative - improving the competitiveness of the agricultural sector, the use of country competitive advantages, improving the investment climate, increasing innovation activity, rural development.

2) Forced - intensification of growth factors and upgrading to a high-tech level of development of the agricultural sector.

Modernization of agro-industrial production on the basis of innovative technological development will ensure resource saving and greening of the agricultural sector, will create the necessary conditions for the growth of labor productivity.

According to the developers of the document, it is expected to increase the volume of financing of transparent and easily administered instruments of state support for the industry, the development of new types of subsidy.

The main factors of crop production development in the long term are:

- $\quad$ assimilation of advanced technologies of intensive land reclamation;

- improvement of treatment methods of soil and sowing, widespread use of resource-saving technologies in crop farming;

- of the efficiency of applied and new biofertilizers, plant protection products;

- introduction of sustainable and productive crops into production, development of elite seed production;

- introduction of efficient agricultural machinery.

In order to achieve the objectives of the State Program for Development of Agriculture and Regulation of Agricultural Commodity Markets for 2013-2020, the solution of the following tasks are envisaged [4]:

- development of material, technical and technological base of selection and seed production;

- increase in innovative activity of the agro-industrial complex;

- development of the biotechnologies;

- development of conditions for increase in the utilization efficiency of agricultural land.

In accordance with the Strategy of innovative development of the Russian Federation until 2020, global and regional challenges actualize the need to intensify the development of narrow areas of research and technological developments [5].

In accordance with the Forecast of scientific and technological development of agro-industrial complex for the period up to 2030, the most important direction of development of domestic crop production is domestic seed production.

The priority of innovative development of agricultural development is the increase of state support of the agrarian science, the formulation and implementation of regional programs to increase scientific and technical level of the agroindustrial complex with account of the development of bio-industry and bio-resources.

In accordance with the Strategy of innovative development of agro-industrial complex of the Russian Federation for the period up to 2020, in the crop production of the Russian Federation more than $70 \%$ of agricultural producers use the extensive and outdated technologies, poor quality seeds, apply minimal amounts of mineral fertilizers, means of plant protection. This creates a reserve for the growth of crop production, through the introduction of very expensive innovative technologies as well.

The Strategy of innovative development of the agro-industrial complex of the Russian Federation for the period up to 2020 considers two scenarios for the development of agro-industrial production: 
1. Local innovative development is a minor improvement of the existing mechanisms of state material and technical support for the development of crop production. This will allow maintaining the achieved trends of gradual technological development and stability in crop production. It will create conditions for the intensification of the industry development due to the most innovative active business representatives, widely using foreign technologies, machinery and seed.

2. Large-scale innovative development - the transition to progressive mechanisms of comprehensive state support for the modernization of the agricultural sector. The central focus on this scenario is given to the development of domestic agricultural science and innovation transfer systems, the development of state-private partnership in the projects of innovative development of crop production.

The main directions of innovative development of the agro-industrial complex, including crop production, are defined:

1. Increasing the efficiency of agricultural science.

2. Development of infrastructure for innovative development of the industry, as well as scientific organizations and universities.

3. Increase in innovation receptivity and activity of education.

4. Promotion of innovation in the agro-industrial complex [6].

According to the developers of the Strategy of socio-economic development of Northwestern Federal District for the period up to 2020, the most important strategic economic goals are [7]:

- modernization and innovative development of key sectors of the economy of the Federal district, increasing the share of innovative products in the gross regional product to $25 \%$ in the Federal district;

- development of agro-industrial production through the introduction of innovative technologies, cooperation of small farms, restoration of livestock population and agricultural land. The industry's target is to achieve $4.5-5 \%$ of the average annual growth rate of agricultural production.

In accordance with the Strategy of socio-economic development of the Pskov region until 2020, the development of the agro-industrial complex belongs to sector 1 of the priority group [8].

The main objectives of the development of the agro-industrial complex in the medium term are [9]:

- increase in the competitiveness of the basic specialization of the agro-industrial complex of the Pskov region. Development of unique directions, demanding modern technologies and innovations;

- diversification of the agro-industrial complex of the region: development of "local" and new sectors, capable of becoming basic in the future;

- increase in the productivity of all factors of production (labor, land, production assets, etc.) in agriculture.

The main objectives of the development of crop production until 2025 are:

- improving competitiveness on the basis of innovative technologies;

- formation of innovative agro-park ;

- increase in the efficiency of use of all production factors : labor, land, production assets. It is planned to stimulate the improvement of the technological level of existing agricultural organizations.

The basic priorities of crop production development are defined:

- growth of production volumes of the main crops due to expansion of acreage and increase of their yields;

- implementation of innovative technologies and modernization of the industry.

In accordance with the Territorial planning scheme, six areas of specialization of agricultural production can be identified in the region.

In the long-term, the positive dynamics of agricultural production should be maintained, through the development of biotechnologies and selection and genetic innovations as well. Biotechnologies make it possible to solve not only economic but also environmental problems. Selection and genetic innovations provide agricultural goods producers with high-yielding plant varieties resistant to difficult environments, as well as to diseases and pests.

In accordance with the sub-program "Development of sub-sector crop production" of the State program "Development of agriculture of the Pskov region for 2013-2020", the main objectives of crop production development are [10]:

- $\quad$ growth of economic efficiency of regional crop production;

- improving the efficiency of farmland use;

- expansion of the reclamation of farmland.

According to the authors of the Program "Development of agriculture of the Pskov region for 2013-2020" the reasons for the low competitiveness of crop production lie in the low level of use of the achievements of selection and seed production, the weak provision of mineral fertilizers and plant protection products, the high level of exhaustion of the material and technical base of production and processing of crop products [10].

In accordance with the Investment strategy of the Pskov region until 2020, there are certain competitive advantages for the development of agriculture in the region [11].

\section{Conclusion}

Thus, the main priorities of innovative development of crop production are:

- $\quad$ increasing the productivity of land resources in use;

- development and large-scale use of biotechnologies, support of elite seed production; 
- modernization of material and technical base towards resource saving and increase of labor productivity;

- implementation of cooperative relations in the agro-food market [12].

Technological multistructurality of agro-industrial production of the Pskov region, as well as the predominance of backward technologies in some sectors of crop production is becoming one of the main factors negatively affecting the development of crop production [13].

In regional crop production, more than $90 \%$ of agricultural goods producers grow and process products using extensive and outdated technologies, use low-quality seed material, apply extremely limited amounts of mineral fertilizers and plant protection products.

Despite this, the regional indicators of grain and leguminous crops yield allow us to speak about the success of innovation-active enterprises in the cultivation of these crops. This means that regional crop production has a significant reserve to increase the results.

The use of the reserve is impossible without a strategic approach - a coordinated vision of strategic priorities.

\section{References}

1. I.S. Sandu, S.N.,Glagolev, A.I. Doshanova, A.S. Troshin, S.N. Lomachenko, Formation features of higher school innovation model in modern conditions. International Business Management, 9(6), 1102-1107 (2015).

2. Federal'nyj zakon "O strategicheskom planirovanii v Rossijskoj Federatsii" ot 28.06.2014 N 172-FZ. Retrieved from: http://www.consultant.ru/document/cons_doc_LAW_164841/. Accessed: 26.11.2018 (2014). [in Rus.].

3. I.S. Sandu, M.Y. Veselovsky, E.I. Semyonova, A.I. Doshchanova, A.V. Fedotov, Innovative aspects of development of the customs union under the new economic conditions. Problems and prospects. Journal of Applied Economic Sciences, 6(36), 855-862 (2015).

4. Postanovlenie Pravitel'stva Rossijskoj Federatsii “Gosudarstvennaya programma razvitiya sel'skogo hozyajstva i regulirovaniya rynkov sel'skohozyajstvennoj produkcii, syr'ya i prodovol'stviya na 2013-2020 gg." Ot 14.07.2012 N 717. Retrieved from: http://base.garant.ru/70210644/. Accessed: 26.11.2018 (2012). [in Rus.].

5. Rasporiyajenie Pravitel'stva Rossijskoj Federatsii “Ob utverjdenii Strategii innovacionnogo razvitiya Rossijskoj Federacii do 2020 g.” ot 08.12.2011 № 2227-p. Retrieved from: http://www.garant.ru/products/ipo/prime/doc/70006124/. Accessed: 26.11.2018 (2011). [in Rus.].

6. E.Skvortcov, E. Skvortsova, I. Sandu, G. Iovlev, Transition of agriculture to digital, intellectual and robotics technologies. Economy of Region, 3(14), 1014-1028 (2018).

7. Rasporiyajenie Pravitel'stva Rossijskoj Federatsii "Ob utverjdenii Strategii social'no-ehkonomicheskogo razvitiya Severo-Zapadnogo federal'nogo okruga na period do 2020 g.” ot 18.11.2011 № 2074-p. Retrieved from: http://docs.cntd.ru/document/902317621. Accessed: 26.11 .2018 (2011). [in Rus.].

8. I.S. Sandu, M.Y. Veselovsky, E.I. Semyonova, A.V. Fedotov, A.I. Doshchanova, Methodological aspects of social and economic efficiency of the regional activities. Journal of Advanced Research in Law and Economics, 3, 650-659 (2015).

9. Rasporiyajenie Administracii Pskovskoj oblasti “Ob utverjdenii Strategii social'no-ehkonomicheskogo razvitiya Pskovskoj oblasti do 2020 g.” ot 16.07.2010 № 193-p. Retrieved from: http://docs.cntd.ru/document/924021554/. Accessed: 26.11 .2018 (2010). [in Rus.].

10. Postanovlenie Administracii Pskovskoy oblasti “Ob utverjdenii Gosudarstvennoyj programmi "Razvitie sel'skogo hozyajstva Pskovskoj oblasti na 2013-2020 gg." ot 11.04.2013 N 161. Retrieved from: http://cx.pskov.ru/doc/documents?tag=177/. Accessed: 26.11.2018 (2013). [in Rus.].

11. A.S. Troshin, I.S. Sandu, A.I. Doshchanova, Innovation and investment component in the development strategy of the region. Agro-Industrial Complex: Economy, Management, 2, 29-35 (2018). [in Rus.].

12. A.S. Troshin, I.S. Sandu, S.V. Kupriyanov, E. Stryabkova, H.F.D. Saldanha, Role and place of economic mechanism in modern conditions. Life Science Journal, 11(10s), 487-490 (2014).

13. I.S. Sandu, N.E. Ryzhenkova, Innovative development of agricultural production: analysis and priorities. Scientific Review: Theory and Practice, 4, 6-16 (2017). [in Rus.]. 